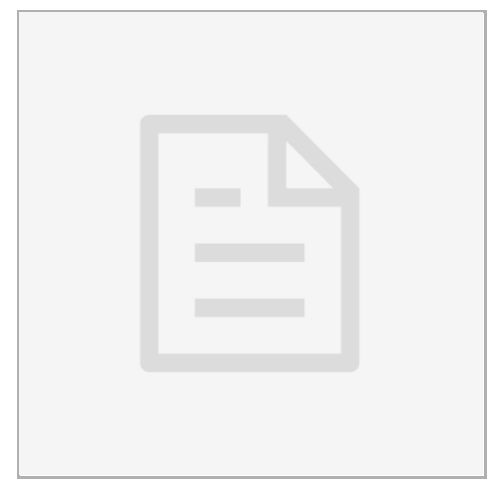

VERSION 1

JUN 12, 2019

\section{OPEN ӘaCcess}

\section{DOI:}

dx.doi.org/10.17504/protocol s.io.335gqq6

Collection Citation: Lev Tsypin, Aaron Turkewitz 2019. Seminavis robusta protocol collection. protocols.io https://dx.doi.org/10.17504/p rotocols.io.335gqq6

License: This is an open access collection distributed under the terms of the Creative Commons Attribution License, which permits unrestricted use, distribution, and reproduction in any medium, provided the original author and source are credited

Protocol status: Working We used these protocols over the course of a year, trying to develop tools to genetically transform the diatom Seminavis robusta. We were not successful in the transformation, but these protocols allowed us to culture the cells in our lab and to determine drug sensitivity. We believe that these protocols will be useful to future researchers interested in this organism.

\section{(3) Seminavis robusta protocol collection V.1}

\author{
Lev Tsypin ${ }^{1}$, Aaron Turkewitz ${ }^{2}$
}

${ }^{1}$ California Institute of Technology; ${ }^{2}$ University of Chicago<smiles>C1CCCCCCCC1</smiles>

\section{Lev Tsypin}

\section{ABSTRACT}

This is a collection of media, reagents, and protocols for the cultivation and manipulation of the diatom Seminavis robusta. Our hope is that these documents will help future researchers develop genetic tools for studying this organism.

\title{
Created: Jun 12, 2019
}


Last Modified: Jun 12, 2019

COLLECTION integer ID:

24413

\section{FILES}

\section{Protocol}

NAME

Media and reagents for Seminavis robusta cultivation and experiments

\section{VERSION 1}

CREATED BY

Lev Tsypin

\section{Protocol}

NAME

Cultivation of Seminavis robusta

\section{VERSION 1}

CREATED BY

Lev Tsypin

OPEN $\rightarrow$

\section{Protocol}

NAME

Cell deposition and drug sensitivity assay

\section{VERSION 1}

CREATED BY

Lev Tsypin

OPEN $\rightarrow$ 